\title{
3.10 THE EVOLVING ACADEMIC FIELD OF LEADERSHIP IN ROMANIAN RESEARCH AND EDUCATION
}

\begin{abstract}
Summary: After a hiatus of more than 40 years of communism and a transition period of more than 20 years, the Romanian society begins to understand the importance of leadership in the economic, political and educational arenas. The main responsible factors for the growing awareness of the need of well performing leadership in all the arenas of social life are the current socio-economic turbulences that directly impact citizens' standard of living and not a growing body of research and education in leadership. In this context, our research scope is to assess the progress made by the academic field of leadership in Romanian research and education, highlighting the resources it has for developing sustainable leadership models. For this purpose, we will identify and analyse the existing academic programmes in leadership, past and current research projects and the Romanian literature in the field. We will study their potential to produce leadership practices and models relevant for today's instable and challenging organizational environment. Based on these findings, we will also explore the measure in which Romanian leadership research manages to transfer its findings to the private and public sectors, in order to contribute to the overall competitiveness of the Romanian business environment. We will use a qualitative and holistic methodology based mainly on secondary research.
\end{abstract}

Keywords: leadership, Romanian leadership models

\section{INTRODUCTION}

"The communist dictatorship in Romania has flattened society and made initiative, critical thinking and innovation dangerous" (Dalton and Kennedy, 2007, p. 233), which, in turn, has affected managerial culture, leadership practices and entrepreneurship development.

After a hiatus of more than 40 years of communism and a transition period of more than 20 years, Romanian society begins to understand the importance of leadership in the economic, political and educational arena. Interestingly, the main responsible factors of the growing awareness of the need for well performing leadership in all the arenas of social and economic life are the current socio-economic turbulences that directly impact citizens' standard of living and less a growing body of research and education in leadership.

In this context, our research scope is to assess the progress made by the academic field of leadership in Romanian research and education, identifying the resources it has for developing sustainable leadership models and how it relates to possible transfers of knowledge to the real economy.

For this purpose, we will identify and analyse past and existing Romanian literature in the field and available academic leadership programmes. We will study their potential to produce leadership practices and models relevant for today's unstable and challenging Romanian organizational environment. We will use a qualitative and holistic methodology based mainly on secondary research.

\section{LEADERSHIP AND MANAGERIAL CULTURE IN ROMANIA}

From a historical point of view, "Romanian cultural history stresses an autocratic leadership style due to strong historic elements of economic centralization and the structural remains of communism. (...) in Romania there is a strong value on traditionalism, and managers lean towards a more task oriented leadership style" (Fein et al., 2010, p. 368). 
During the communist regime, an extended industrialization process was carried out, which needed specific managerial structures. Within those structures, "managers were simultaneously immensely powerful and weak" (Dalton and Kennedy, 2007, p. 248), because of limited decision power, being more administrators than managers. One of the few academic works in management was Nicolescu's book "The improvement of the organization of managing enterprises" (1986), in which an analysis of 30 organizations is carried out, summing up a series of best practices in management in the communist regime.

The closed political regime, the post-communism transformational process and, further on, the increasing global economic integration (Steyrer et al., 2006), explain partially the present Romanian leadership and management preferences and styles, that nowadays have embraced Western, mainly Anglo - American principles of management. "The influences of the transition process, including the restructuring of the firm and its culture, is seen as an important factor for both stability and change in leadership behaviour in Romania" (Steyrer et al. 2006) ${ }^{9}$

But what do we know about Romanian leadership and managerial culture?

Fortunately, the majority of studies converge in their characterization of the typical Romanian leadership style. For example, Finlay, J., L., Mark, N., Catana, Gh. Catana (Dec. 2003) show that, in Romania, the manager - employee relation follows Weber's rational legal style of leadership. Their conclusion is based, among others, on the fact that in Romania, management is perceived as a group phenomenon, involving employees' strict loyalty, good managerial communication skills, short term orientation.

Steyrer et al. (2006) carry out a complex and comparative analysis of leadership in Romania, Estonia, Germany and Austria. The conclusion regarding Romania is in line with previous research and indicates a high self-protected behaviour (the highest in the group of countries mentioned), a patriarchal, authoritative, risk adverse, non-participative, but "humane" leadership style.

Dalton and Kennedy (2007) underline in their study of several Romanian organizations that the Romanian leadership style shows a strong tendency toward decentralization, which is commonly obtained by the figure of a "project leader". According to the authors, middle and lower Romanian managers tend sometimes not to trust their own judgements, but to follow orders. Also, they might embrace a passive attitude, manifest a preference for risk avoidance and be likely to use personal authority that might jeopardize team working, motivation and initiative. Dalton and Kennedy (2007) also emphasise that part of the Romanian management culture is based on formalism and status, a recurrent conclusion in organizational culture studies about Romania.

A recent and complex study of the company Human Synergistic Romania (2011), carried out a national survey on a sample of more than 800 employees, 180 business leaders and 50 Human Resources managers. The results indicated that Romanian leaders are perceived to: a) lead people controlling in details the execution of tasks, b) be more stressed than foreign leaders, c) carry out their task more in order not to break the rules of the organizations, and less in order to follow and accomplish constructive aspirations; Romanian leaders are, again, perceived to be defensive, rather than constructive, which impacts on strategy formulation.

\footnotetext{
${ }^{9}$ For a detailed and in depth analysis of the historical factors that explain management culture in Romania or other Eastern countries, see Dalton and Kennedy (2007)
} 


\section{ROMANIAN AND FOREIGN ACADEMIC LITERATURE ON ROMANIAN LEADERSHIP}

Romanian literature is still in an incipient stage in what concerns leadership. After six years after the fall of the communist regime, Romanian management literature was considered to be "a gross adaptation of Western translations, mainly French and American, and virtually no attention has been paid to the specific of national culture. Researchers in management are sponsored to carry out mainly quantitative studies in the hope of squeezing the complexity of managerial life" (Kelemen, 1995, p. 8).

Currently, experts make similar considerations: "there is a low level of development of domestic leadership models, both in academic research as in practice" (Neesham et al, 2008). According to the authors mentioned, a limited number of books regarding leadership was translated in Romanian language, the academic textbooks are also just a few and the majority of books written by Romanian authors mainly focus on management. The effect is that there is no relevant transfer of concepts and knowledge of leadership in the Romanian economy.

One exception from the practice of ignoring Romanian organizational behaviour, probably based on a local incapacity to run quantitative studies in Romanian organizations, is Luca's book (2005), "Employescu". The author uses Gallup surveys to interview Romanian managers and employees and demonstrates that Romania has similar values with other Balkan countries, like the great distance to authority, high degree of collectivism, feminism, high degree of risk avoidance and short term orientation, which situates the country in an opposite situation from that of Anglo-Saxon countries.

Therefore Luca underlines the paradox that although Romania has borrowed Anglo-Saxon practices of management and the work force does have expectations of a participative and consultative organizational environment, the local organizational culture with its great distance to authority, high degree of collectivism, feminism, high degree of risk avoidance and short term orientation, may favour clashes between employees and managers unless awareness is developed for this situation.

Regarding the main directions of Romanian research in leadership, Neesham et al (2008) show that most of the studies are limited to political or public leadership, and less to business leadership. Unfortunately, academic interest in the field is can be hardly correlated with the increasing professionalization of public management and/or leadership, despite positive appreciations of Mos and Bibu (2012), in their study of leadership style in four Romanian municipalities and 120 respondents. The authors show (Mos, Bibu, 2012, pg. 86) "that application of leadership in public administration in Romania has begun", the results of their studies indication more flexibility, sympathy and openness of Romanian public managers.

Based on our literature review, we conclude that past and current research directions are related to political leadership, educational leadership (Korka, 2002, 2006, 2008; Miron, 2008), public leadership/public governance, in conjunction with public management, including European's Union governance (Popescu et al, 2012). This research agenda is partially explainable by the societal and economic evolutions of a country which is still trying to consolidate its democratic process, political leadership and administrative systems. As Mos and Bibu state (2012, pp. 86) "major changes in the socio-political environment of each country, need diversity and complexity of problems arising in various areas results in an acute requirement of promoting leadership in public administration". Academics, as part of the intellectual nucleus involved in the democratic transformations of society, have focused primarily on analysing their own organizations - the universities - thus generating a flourishing literature on the role, leadership and management of higher education institutions. The political "battle" needed professionalization, and in the context of an almost empty arena, professional and pseudo professional political leaders and experts have materialized their 
knowledge in articles, specialized study programmes and research projects. In addition, European membership in 2007 had as a consequence, on the entire academic publications sector, a huge series of topics addressed by socio-economic researchers, including the European Union's leadership.

Interestingly, as Neesham et al (2008) noticed, research on leadership is not that developed in business. Some factors that could explain this deficit of research and interest are:

a) the insufficient consolidation of the market economy;

b) a still unsophisticated business environment;

c) the absence, in the beginning, and the inconsistency, at present, of leadership and management study programmes.

This also partially explains Pandelica et al.'s considerations regarding the co-existence of the dualistic old and new management practices and values: "although the Romanian economy works according to market economy principles, values and mechanisms (...) at present, considering the employees' values and attitudes, on the one hand, we can identify, modern values strongly associated with reforms and changes and on the other hand, values pertaining to a slowing-down reforming process mentality”.(Pandelica et al., 2010, p. 255).

In contrast with the development of the Romanian leadership literature, the curious inquiry of Western researchers has generated an appreciable corpus of knowledge on leadership issues in the Easter European, transition countries, although a lot of the research is mixed.

Steyrer, J. et al. (2006) conducted a synthetic analysis of the development of leadership literature for the case of Romania. The authors emphasize at the beginning of their research that the main problem seems to be the rigid organizational culture of companies, probably as a reflection of the need to better manage the changes from egalitarian to market based values. The route of research continues, according to the authors, with motivational theory issues, leader traits, behaviour and contingency theory and the impact of Western managerial culture on Romanian organizational culture.

Năstase $(2004,2005,2007,2008)$ generally enriches Romanian literature on leadership and general management, with original contributions, both in Romanian and in English, focusing on organizational culture, development of managerial and leadership skills or the relation between the knowledge based economy and leadership development.

Littrell and Lapadus (2005) develop a comparative research between Romania, Germany and the UK, in which they underline, regarding Romania, the existence of a high power distance score, high uncertainty avoidance and underline the desirable leader behaviour in Romania which is to reconcile conflictive demands and reduce disorder in the system.

Aioanei (2006) studies the most common leadership behaviours in Romania. She concludes that 55 percent of Romanian leaders are authoritarian and 45 percent democratic. She also reveals that Romanian leaders use to retain the final decision, making use of coercion. Aioanei (2006) underlines that the autocratic style is higher in state-owned enterprises; her general conclusion is that Romanian leaders fit in the "Military Man" pattern, although expectations are to move on to a more participative and democratic leadership style.

In their research, Fein et al. (2010) aim at examining preferences for both transformational and transactional leadership behaviour for gender- and age-based cohort differences. They find that there are differences in preferences for leadership behaviour based on age cohorts that reached maturity before or after the fall of Ceaușescu during the 1989 revolution and that female participants showed a greater preference for transformational leadership behaviours relative to transactional leadership behaviours.

Barbu and Nastase (2010) address the issue of new challenges faced by leaders to the significant socio-economical transformations and economic crisis moments, i.e, organzaitional transformations in managerial and leadership path due to changes in the external environment. The study also analysis new particularities in leadership and 
management processes, like the use of participative style on a large scale, due to the need of constantly learning. The authors conclude that "managing organization "on change paths" means understanding, discipline, creativity and ingenuity" (pp. 130), but also that the economic crises usually make leaders to be better prepared to run organizations. In the words of the authors, "crisis is a time when both opportunity and danger are present and therefore leaders should be good in transforming danger into opportunities in order to value the situations at their best" (pp. 133).

Nicolae (2010) in her book "Leadership. A Global and cultural approach" enriches the Romanian academic leadership literature by an interdisciplinary and intercultural approach. The main contribution of the book, written in English, is the synthetic but consistent analysis of leadership models and approaches belonging to very different historical epochs, from Confucius to Juran and Deming.

Ispas (2012) uses a traditional approach to leadership, in the business area, on a specific industry: the Romanian hotel industry. She tests the opinions of both managers and employees on how these perceive four leadership styles (the autocratic, participative, transformational and transactional one). Despite the high practical value of the paper, the sample was limited to 20 managers and 30 employees. According to the results reported, "managers perceived their own leadership style more autocratic and participative meanwhile employees perceived them to be more autocratic and transformational" (pp. 294). In our opinion, despite the simplicity of the study, it is valuable mostly because it opens the doors for more applicable, business case based research in Romania.

Other study with an applicative nature is "The Impact of Motivation Through Leadership on Group Performance", by Tebelian (2012). The study aims at testing the influence that a leadership style has on the performance of employees. The two styles that are tested are "transformational" and "servant" leadership styles. Defines the servant style as that leadership that "transcends the boundaries of transformational leadership by simply aligning the motives that drive the leaders with those that drive their disciples" (pp. 315-316). Although the conclusions regarding a direct relation between motivation and leadership style lack clarity, one final though is worth to quote, as it shows signs of maturity in leadership research: 'in order for the leadership theory to continue to exist, it must be admitted and accepted that the leadership is a complex process that interacts with behavioural, relational and situational elements. The leadership does not concern only the individual but also resides at the individual, dyadic, group and organizational levels." (Tebelian, pp. 322).

\section{LEADERSHIP TRAINING PROGRAMMES AND COURSES IN ROMANIA}

According to Fein et al. (2010, p. 365), "leadership training is the type of management training that includes a primary focus on communication with various types of people, primarily to influence individuals to exert effort towards organizational objectives".

The Romanian literature regarding the concept of leadership still needs to be improved, but formal leadership courses are better represented on the Romanian market, and in recent years a growth has been noticed. In the following section we will look at academic courses and at the training courses offered by non-academic organizations.

There are still no specific leadership courses for undergraduate students at university level as opposed to other universities around Europe. For example the University of Exeter in the UK offers two undergraduate programmes that focus solely on leadership: Leadership and Politics and Management with Leadership ${ }^{10}$. While the specific courses on leadership are still absent from most study programmes, in recent years Romanian universities offering majors in

\footnotetext{
${ }^{10} \mathrm{http}: / /$ business-school.exeter.ac.uk/programmes/undergraduate/businessandmanagement/
} 
business and management have started to offer courses focused on soft skills such as intercultural communication, effective listening, negotiation etc. Soft skills can lead to the improvement or the development of leadership skills.

The situation is improved in master programmes as most of them offer leadership courses. Most programmes focus on leadership and organizational behaviour. Most of the MBA type courses offered by the Bucharest University of Economic Studies, (such as the Canadian $\mathrm{MBA}^{11}$ and $\mathrm{INDE}^{12}$ ) started as collaborations with international partners. As a consequence of the latter's expert input, their curriculum has a strong Western theoretical content and relatively little reference is made to Romanian leadership practices.

Some of the best known programmes on the market are: ASEBUSS (www.asebuss.ro), Canadian MBA (www.bsm-mba.ro), INDE (www.inde.ro); WU Executive Academy MBA (www.executiveacademy.at/remba); MBA Open University Business School Programme (www.codecs.ro/website/ro/documente/oferta/mba/mba.htm), organized in Romania by CODECS; Central European University (CEU) Business School (www.ceubusiness.org); Sheffield University through City College (www.city.academic.gr/exed) and City University of Seattle (www.intercollegeibs.ro). This is a very dynamic area and there lately we can notice many offers on the market.

Another interesting programme focusing on Romanian leadership coming from the academic environment is the LIDEROM Project, managed by academics from the Bucharest University of Economics during the period 2007-2010. The aim of the project was to create a knowledge base for business leadership education, research and practice in Romania, and more importantly create a model of good practices in leadership which takes into consideration the specific characteristics of Romanian business culture and, at the same time, is efficient in motivating the human resources of an economy going through considerable change. The aim of the project coincided with one of the three strategic objectives of the Research, Development and Innovation (RDI) national system, which refers to the creation of knowledge, by getting excellent results in research and related technology, to increase the visibility of Romanian research at international level and the transfer of these results to social and economic practice.

The Project had five objectives, and those were: (1) to determine the level of development reached by leadership studies and research in Romania; (2) to choose international best practices in the field; (3) to develop a methodology for knowledge and know-how transfer from developed organizational cultures to the Romanian context; (4) to encourage local conceptions of leadership, based on experiences in the Romanian business culture; and (5) to create an online portal that would help Romanian businesses in using various models of excellence in leadership according to their own organizational development needs.

The research was conducted in two stages. The first stage of the project consisted in performing the literature review on leadership and recognizing international models of leadership excellence. The review is quite comprehensive and is based on information collected from over 50 international databases, and includes examples referring to transformational leadership, situational leadership, positive leadership and psychological capital. The second stage of the project revolved around data collection and conducting interviews with international specialists in business leadership. The working team of the project conducted interviews with top specialists in leading organizations in the UK, the Netherlands and Australia. In communicating its conclusions, the team has relied on knowhow shared by the Prince of Wales International Business Leaders Forum (represented by Lord Alan Watson of Richmond), the Centre for Management Development at London

\footnotetext{
${ }^{11} \mathrm{http}: / / \mathrm{www} \cdot \mathrm{bsm}-\mathrm{mba} \cdot \mathrm{ro} /$

$12 \mathrm{http}: / / \mathrm{www}$. inde.ro/
} 
Business School, the National School of Government (London), the Tavistock Institute (London), the Inspirational Development Group (London), the International Business and Management Studies Institute at the University of the Hague, the Institute of Social Studies (the Hague), Clingendael-Netherlands Institute of International Relations (the Hague), Maastricht School of Management, the International Business Administration Program at Vrije University (Amsterdam), the Department of Management at Monash University (Melbourne, Australia) and the Graduate School of Business at Monash University (Melbourne, Australia).

Aside from research programmes developed by the academia which obviously have a more theoretical approach there is a growing interest in the field of leadership from the business people and entrepreneurs. There is a growing trend for leadership courses organized in companies as part of career development programmes or HR strategy and usually with inhouse trainers, about whom information is not publicly accessible and therefore is far more difficult to obtain. These leadership courses are usually aimed at middle and top management.

A unique leadership development perspective has been promoted and delivered by the CODECS Foundation for Leadership. The CODECS Foundation for Leadership was created in February 2001 by S.C. CODECS S.A ${ }^{13}$. The Foundation is a non-political organization, without a working scope, nongovernmental, with the purpose of creating, developing and consolidating the organizational leadership culture in Romania, by contributing to the creation of new generations of leaders, capable of triggering the change management mechanisms, using professional, knowledge, influence and connection excellence. Some of the Foundation's key principles are: raising the general public's interest in the topic, promoting academic and professional excellence in the field, and fostering internal and international cooperation for leadership development.

The most known educational project offered by the Foundation is "Leaders of the Third Millennium" (LTM), run at national level in schools and high-schools, in partnership with the British Council as founding partner. Starting with 2006, the Ministry of Education, Research, Youth and Sports became a partner. The purpose of the programme is to develop leadership competencies in students and teachers. The programme modules are focused on one ability that the students develop, amongst which the following are offered: communication, team work, emotional intelligence, negotiation, conflict solving, management, leadership, personal development etc. The values promoted are trust, honesty, competence, performance and civic activity courage.

The offer for leadership courses includes a rich component of personal development courses which have flourished particularly after the economic crisis set in. These are usually training courses of one or two days, typically offering to develop the leader inside the course participant by developing interpersonal abilities, time management skills, communication skills, sales techniques, marketing abilities. These courses are offered by a large variety of Romanian or expatriates run businesses. The need on the market for such courses is selfevident and, since the existence of the European structural funding programmes, particularly those developing the human resources, there has been an increase of the providers and the types of courses offered. This is a good development as there are courses aiming at the grassroots levels of employees, not only at the middle and top management of organizations.

Another method of presenting the developments in the field of leadership is by organising conferences. The first leadership conference in Romania, as it was presented by the organisers, had as guest speaker Stephen R. Covey, which is one of the leading specialist in inspirational leadership. The conference was organised by Human Capital Solutions with the

\footnotetext{
${ }^{13} \mathrm{http}: / / \mathrm{www} \cdot \operatorname{codecs} . \mathrm{ro} / \mathrm{en} /$ foundation/
} 
Financial Paper in November 2006. There were approximately 450 participants from state run and private companies, NGOs, Romanian as well as foreign companies.

According to Covey true leadership is that based on character ethics, and focuses on the main idea that human efficiency is governed by principles that act as natural laws of the human dimension as real and unpredictable in real life as the laws of gravitation in the physics dimension. Covey considers that there are no born leaders but one cannot create a leader. True leaders are self-made because leadership is a personal choice not just a position one applies for or fills in.

In recent years there has been a positive development and mainly a focus on young people and teaching them about leadership. This focus is coming especially from student organisaions. AIESEC (Association Internationale des Étudiants en Sciences Économiques et Commerciales) has been organizing for the past years conferences that focus on leadership. In 2010 they organized a conference titled "Leadership Talks" where key figures from the business environment, sports, culture, literature, arts and advertising were invited to discuss what being a leader means. In November 2011 there was another conference titled "Romanian Youth Leadership Forum" which had over 500 participants.

\section{CONCLUSION}

The research of the specific situation of Romanian leadership practices and preferred styles is still only at the beginning and relatively fragmented, however showing clear signs of accelerated development. Because research results are scarce, even though the market demand for leadership training is increasing, the academic community is not sufficiently ready to offer leadership courses and materials based on the realities of the Romanian business environment. Hopefully more importance will be given to the study of Romanian leadership practices not only focusing on theoretical aspect but also making a connection to the business, political, socio-cultural environment.

Leadership courses are still perceived as elite products for top or middle management and not as courses which are necessary to shape the mindset of tomorrow's decision makers or to increase the responsibilities and productivity of today's work force.

The world today is not going just through a financial crisis but also a crisis of values and principles. It is important to have leaders that can help lead people through times of uncertainty and guide them towards a better future.

This is even more important for Romanian which has been going through a transition period for the last 22 years and is in clear need of leadership and vision. It is important to understand that leadership is not just a theoretical field of study and that is has very practical applicability which can improve Romanian society. True leader are not necessarily born but through the proper education and inspiration from positive role models in society we can become leaders that inspire those around us. One mustn't think that being leader means that one should be influencing an entire country but we should focus on making a difference in the communities around us. We must focus on developing ourselves and reaching our full potential and aspire to have the qualities we wish to see in our leaders. Each individual should strive to become a role model in his or her community and try to influence the lives of those around him or her in a positive manner. 


\section{REFERENCES}

1. Aioanei, I. (2006) Leadership in Romania, Journal of Organizational Change Management, Vol. 19, No. 6, pp. 705-712

2. Barbu, M., Nastase, M. (2010), Change Leadership and the Worldwide Crisis, Review of International Comparative Management, Vol., 11, Issue 1, pp. 129 -138

3. Dalton, K., Kennedy, L. (2007) Management culture in Romania: Patterns of change and resistance, Journal for East European Management Studies, Vol. 12, Issue 3, pp. 232-259

4. Fein, E., C., Tziner, A., Vasiliu, C. (2010), Age cohort effects, gender, and Romanian leadership preferences", Journal of Management Development, Vol. 29 Issue 4, pp. 364 376

5. Finlay, J., Neal, M., Catana A., Catana D. (2003) Anticipated Management Styles: Viewpoints of Potential Women Employees from Selected Evolving Economies, Economic and Business Review for Central and South - Eastern Europe; Vol. 5, Issue 4, pp. 285-307

6. Ispas, A. (2012), The Perceived Leadership Style and Employee Performance in Hotel Industry - a Dual Approach, Review of International Comparative Management, Vol. 13, Issue 2, pp. 257-264

7. Kelemen, M., (1995) How British and Romanian directors compare, Management Development Review, Vol. 8, Issue 3, pp. $24-31$

8. Korka, M. (2002) Universităţile româneşti în faţa integrării în spaţiul european de învăţământ superior, Politehnica Publishing, Bucharest

9. Korka, M. (2006) Role of universities in the knowledge-based society and economy. a public policy perspective, The proceedings of the international conference „The future of Europe: challenges and opportunities", ASE Publishing, Bucharest

10. Korka, M. (2008), Reproiectarea parteneriatului şi a leadershipului în universităţi, International Research Conference "Change Leadership in Romania's New Economy" Curtea de Argeş, România, pp. 40-46

11. Korka, M., (coord.) (2009) Educaţie de calitate pentru piaţa muncii, Rezultate şi recomandări ale Proiectului Phare 2006/018-147.06.01 „Adaptarea activă a educaţiei universitare la cerinţele pieţei muncii", "Universitară" Publishing House, Bucharest

12. Littrell, R., F., Lapadus, N.,V. (2005) Preferred leadership behaviours: exploratory results from Romania, Germany, and the UK, The Journal of Management Development; Volume 24, Issue 5; pp. 421 - 442

13. Luca, A. (2005). Employeescu, O scurtă caracterizare a angajatului roman, First Edition, Interact Publishing, Bucharest

14. Mos, A., L. , Bibu, N., (2012), Style in the Romanian Public Institutions - the Case of City Halls, Review of International Comparative Management, Vol. 3, Issue 1, pp. 81-87

15. Nastase, M. (2004) Cultura organizationala si cultura manageriala, ASE Publishing, Bucharest

16. Nastase, M. (2005) Managementul aplicativ al organizatiei - jocuri si aplicatii manageriale, studii de caz, ASE Publishing, Bucharest

17. Nastase, M. (2007) Lideri, leadership si organizatia bazata pe cunostinte, ASE Publishing, Bucharest

18. Năstase, M. (2008). Professional competence and leadership within organizations, Economia - seria de management, Vol. 11, Issue 2, pp. 88-94

19. Neesham, C., Nicolae, M., Năftănăilă, I. (2008) Privire de ansamblu asupra cercetării, educaţiei şi practicii în leadershipul în afaceri în România, International Research Conference "Change Leadership in Romania's New Economy" , Curtea de Argeş, România, p. 22-30 
20. Nicolae, E., Nicolae, M., (2008), Valori, mentalităţi şi leadership în România, International Research Conference "Change Leadership in Romania's New Economy", Curtea de Argeş, România, p. 30-40

21. Nicolae, M., (Ed.) (2010) Leadership. A Global and Cultural Approach, ASE Publishing, Bucharest

22. Miron, D., (2008), Educaţia românească privind economia şi afacerile - puncte slabe şi forte, International Research Conference "Change Leadership in Romania's New Economy", Curtea de Argeş, România, pg. 46-58

23. Pandelica, I., Pandelica, A., Dabu B. (2010) Pilot Study Regarding Organizational Culture Dominant Values: Romania's Case, The Business Review, Cambridge, Vol. 14, Issue 2

24. Popescu, D., M., Zlate, D., Ciută, M. (2012), Leadership in the European Union: Significance and Perspectives, Review of International Comparative Management, Vol. 13, Issue 2, pp. 257-264

25. Steyrer, J., Hartz, R., Schiffinger, M. (2006) Leadership in transformation - between local embeddedness and global challenges, Journal for East European Management Studies; Vol. 11, Issue 2, pp. 113-139

26. Tebelian, (2012), The Impact of Motivation Through Leadership on Group Performance, Review of International Comparative Management, Vol. 13, Issue 2, pp. 313-324

27. Human Synergistic Romania (2011), National Research Leadership Impact, retrieved on 20th April 2012, from

28. http://www.humansynergistics.ro/Descarcă\%20Raport\%20Parțialcercetarea $\% 20$ nationala-40-177.html 